\title{
Albuterol enantiomer levels, lung function and QTc interval in patients with acute severe asthma and COPD in the emergency department
}

\author{
Kwang Choon Yee ${ }^{1 \dagger}$, Glenn A Jacobson ${ }^{1 *}$, Richard Wood-Baker ${ }^{2}$ and E Haydn Walters ${ }^{2}$
}

\begin{abstract}
Background: This observational study was designed to investigate plasma levels of albuterol enantiomers among patients with acute severe asthma or COPD presenting to the emergency department, and the relationship with extra-pulmonary cardiac effects (QTc interval) and lung function. Recent reviews have raised concerns about the safety of using large doses of $\beta_{2}$-agonists, especially in patients with underlying cardiovascular comorbidity. It has been demonstrated that significant extrapulmonary effects can be observed in subjects given nebulised (R/S)albuterol at a dose of as little as $6.5 \mathrm{mg}$.

Methods: Blood samples were collected and plasma/serum levels of (R)- and (S)-albuterol enantiomers were determined by LC-MS and LC-MS/MS assay. Extra-pulmonary effects measured at presentation included ECG measurements, serum potassium level and blood sugar level, which were collected from the hospital medical records.

Results: High plasma levels of both enantiomers were observed in some individuals, with median (range) concentrations of $8.2(0.6-24.8)$ and $20.6(0.5-57.3) \mathrm{ng} / \mathrm{mL}$ for (R)- and (S)- albuterol respectively among acute asthma subjects, and $2.1(0.0-16.7)$ to $4.1(0.0-36.1) \mathrm{ng} / \mathrm{mL}$ for (R)- and (S)- albuterol respectively among COPD subjects. Levels were not associated with an improvement in lung function or adverse cardiac effects (prolonged QTC interval).

Conclusions: High plasma concentrations of albuterol were observed in both asthma and COPD patients presenting to the emergency department. Extra-pulmonary cardiac adverse effects (prolonged QTC interval) were not associated with the plasma level of (R)- or (S)-albuterol when administered by inhaler in the emergency department setting. Long-term effect(s) of continuous high circulating albuterol enantiomer concentrations remain unknown, and further investigations are required.
\end{abstract}

\section{Background}

Albuterol (salbutamol), a $\beta_{2}$-agonist, plays an important role in emergency medicine and is the first line medication for relief of shortness of breath during acute asthma exacerbations. Albuterol is also used on a regular basis for the management of chronic obstructive pulmonary disease (COPD), both during stable periods and acute exacerbations [1-3]. Many recent studies and guidelines have indicated that the use of short-acting $\beta_{2}$-agonists on a regular basis will not improve asthma

\footnotetext{
* Correspondence: glenn.jacobson@utas.edu.au

+ Contributed equally

${ }^{1}$ School of Pharmacy, University of Tasmania, Hobart, Tasmania, Australia

Full list of author information is available at the end of the article
}

control, and may even cause deterioration [4-6]. However, regular use of short-acting $\beta_{2}$-agonists such as albuterol is still very common for the management of COPD [1-3].

Albuterol is a chiral compound consisting of (R)- and (S)- enantiomers, and is most commonly administered as a 1:1 racemic mixture ( $r a c-)$. The therapeutic effect of albuterol is supposedly delivered by the (R)-enantiomer [7]. However, (R)- and (S)- albuterol have been found to exhibit different pharmacokinetic properties, where (S)-albuterol has greater bioavailability and a longer half-life than (R)-albuterol $[8,9]$.

These differences in the pharmacokinetics of albuterol enantiomers can contribute to the accumulation of (S)-

\section{SpringerOpen ${ }^{\odot}$}

(C) 2011 Yee et al; licensee Springer. This is an Open Access article distributed under the terms of the Creative Commons Attribution License (http://creativecommons.org/licenses/by/2.0), which permits unrestricted use, distribution, and reproduction in any medium, provided the original work is properly cited. 
albuterol after repeated dosing $[8,10]$. Some studies have claimed that $(\mathrm{S})$-albuterol is not inert, but rather has detrimental physiological effects, including pro-inflammatory and pro-constriction effects $[11,12]$, increases airway responsiveness $[13,14]$ or acts as a functional antagonist [15]. Potential adverse effects of (S)-albuterol have also been suspected since studies found that pure (R)-albuterol is superior in treatment outcomes compared to the equivalent dose of rac-albuterol [16-18]. However, these findings are usually difficult to interpret and are often not translated into clinical studies that compare the therapeutic outcome [19-22]. There are a number of studies indicating that both the immediate therapeutic effects and immediate adverse effects of racalbuterol are delivered solely by $(\mathrm{R})$-albuterol $[9,23,24]$. The weight of evidence to date suggests that (S)-albuterol is inert, but the effects of high levels of (S)-albuterol remain unclear $[19,22]$.

Most of the pharmacokinetic and pharmacodynamic studies of albuterol have been performed on healthy, mildly asthmatic patients, within the generally recommended dose $[8,9,15,23]$. However, patients presenting to the emergency department with exacerbations of asthma and/or COPD are usually heavily reliant on

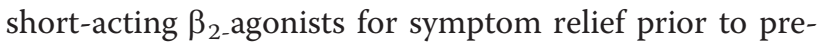
sentation and would be expected to use much higher doses of albuterol. A study has shown that patients who have died from asthma have up to 2.5-fold higher plasma albuterol levels than asthma patients using albuterol at the emergency department [25]. In addition, studies have shown that the significant extrapulmonary effects of inhaled albuterol, which include increased heart rate $[9,24,26,27]$, increased QT interval [26] and decreased plasma potassium level $[9,24,26,28]$ can all occur within the maximum recommended dose. It has been suggested that the presence of $\beta_{2}$-agonists can aggravate the risk of these cardiovascular events, in particular among individuals who have long-term exposure to accumulated doses of $\beta_{2}$-agonist $[27,29]$.

Our preliminary investigations in emergency department presentations have revealed relatively high plasma levels in acute severe asthma patients, with an up to fivefold difference in concentrations of (R)- and (S)-albuterol [30]. The objective of this study was to observe the relationship between (R)- and (S)-albuterol levels and lung function measures, as well as potential extrapulmonary adverse effects, in presentations of acute disease exacerbation seen in a typical emergency department setting.

\section{Method}

\section{Study design}

The study was observational in design and conducted in two separate phases. The study was designed to observe the relationship between albuterol enantiomer levels and lung function measures and potential extrapulmonary adverse effects among patients presenting with exacerbation of asthma and COPD respectively.

The study was conducted at the Department of Emergency Medicine (DEM), Royal Hobart Hospital (RHH), Tasmania, Australia. The study was approved by the State Human Research Ethics Committee in compliance with the Helsinki Declaration, and written informed consent was obtained from all subjects prior to the investigation.

\section{Acute asthma study subjects}

Potential subjects of the study were patients who presented to the DEM with an acute exacerbation of asthma. The inclusion criteria were adult patients, aged between 18 and 65 years, and self-reported rac-albuterol utilisation within $24 \mathrm{~h}$ prior to presentation. Recruitment was convenience sampling in nature and was conducted in two phases over a total period of 18 months.

Patients who had presented to the emergency department for over $12 \mathrm{~h}$ prior before blood sampling were excluded. Moderate to severe asthma exacerbation was diagnosed by independent emergency physicians, in accordance with the National Asthma Council Australia (NAC) guidelines [31].

\section{Acute asthma sample and data collection}

Blood samples $(10 \mathrm{~mL})$ were collected from each subject in potassium EDTA tubes by medical or nursing staff at the DEM. The blood sample was then centrifuged, and the plasma harvested and stored at $-20^{\circ} \mathrm{C}$ until analysis.

History of rac-albuterol use by subjects within the previous $24 \mathrm{~h}$ was obtained from subjects by interview and from medical records. The albuterol utilisation was also converted to defined daily dose (DDD) [32], which was designed to standardise the dose between different types of formulation. One DDD of rac-albuterol was considered equivalent to $800 \mu \mathrm{g}$ of rac-albuterol delivered by pressurised metered dose inhaler (MDI) or 10 mg delivered by nebuliser. The DDD was only used as an estimation of the number of doses of albuterol required during the asthma exacerbation (between different dosage forms), and does not represent the amount of albuterol being delivered or reflect the recommended dose.

Basic demographic information and details of medical treatment during hospital presentation and on the way to hospital were obtained from the hospital medical records. Concomitant use of other asthma medication was recorded. Clinical measures of severity and response to therapy included improvement in percent predicted PEF after $60 \mathrm{~min}$ and a four-point severity score, similar to the Acute Asthma Index (AAI) designed and validated by Rodrigo and Rodrigo [33]. However, a 60-min 
PEF was used instead of the 30-min PEF as used in the AAI, as it was more achievable by emergency department staff in our setting. Respiratory function tests were performed with a Vitalograph ${ }^{\circledR}$ Compact spirometer (Buckingham, UK).

\section{Acute COPD study subjects}

Potential subjects of this study were adult patients presenting to the DEM with exacerbation of COPD over a period of 14 months. Subjects were excluded if they did not have a routine serum sample collected within $4 \mathrm{~h}$ of presentation or were not admitted to the general ward after the DEM presentation. Confirmation of the diagnosis and subject recruitment (convenience sampling) were carried out at the general ward by an independent medical officer from the Department of Respiratory Medicine, $\mathrm{RHH}$.

\section{Acute COPD sample and data collection}

Serum aliquots were obtained from the remaining samples after routine blood examination was performed according to DEM procedures. Routine tests undertaken include full blood examination, electrolyte examination and ECG measurement. The Department of Clinical Chemistry (Pathology), RHH, was informed of each subject's participation, through a secure collaborative network, after written informed consent had been obtained. The remaining serum samples (collected in VACUETTE ${ }^{\circledR}$ Z Serum Sep $\mathrm{C} / \mathrm{A}$ tubes) were then transferred to the investigators after being kept at the Pathology Department (at 4- $8^{\circ} \mathrm{C}$ ) for 7 days as required in accordance with the RHH Pathology serum protocol. After the transfer, serum samples were stored at $-20^{\circ} \mathrm{C}$ until analysis.

Information regarding the potential extrapulmonary adverse effects of albuterol within the $4 \mathrm{~h}$ of DEM presentation, including heart rate (HR), corrected QT (QTc) interval, serum potassium level and blood sugar level (BSL), was collected from hospital medical records. Demographic information and relevant medical history were extracted from medical records. Medication history prior to the ECG measurement and blood sampling, in particular medications known to affect the measurements clinically, was also recorded. ECG measurements were examined by an independent clinician to determine if the recorded QTc intervals were affected by underlying cardiac condition(s) (e.g. heart block). Subjects with a medical or medication history that could interfere with the measurement(s) were excluded from the association analysis.

\section{Analysis of albuterol}

Albuterol enantiomer analysis was performed with a previously published method [34], modified using deuterated rac-albuterol (D3-rac-albuterol; 3-hydroxymethyl$\mathrm{D}_{2}, \alpha-\mathrm{D}_{1}$, obtained from Medical Isotopes, Inc., Pelham, $\mathrm{NH}$ ) as internal standard. In brief, the samples were brought to room temperature, and the internal standard and ammonia buffer were added to each aliquot before solid-phase extraction and analysis by LC-MS or LCMS/MS. The lower limit of quantification (LLoQ) was $0.156 \mathrm{ng} / \mathrm{mL}$ (from $500 \mu \mathrm{L}$ ), and reproducibility (RSD) was $<15 \%$.

\section{Statistical analysis}

One-way factorial ANOVA was used to assess the relationship between severity score and plasma albuterol, and Fisher's protected least significant difference (PLSD) post hoc test was used to assess any statistical significance. Linear regression was used for the relationship between continuous variables. Spearman rank correlation and Mann-Whitney tests were used to assess the relationship between the serum albuterol level and extrapulmonary effects (heart rate, QTc interval, serum potassium level and BSL), which did not exhibit Gaussian distributions. Statistical analyses were undertaken with Statview 5.0.1 (SAS Institute Australia Pty Ltd., NSW, Australia) and SPSS 15.0 for Windows (SPSS Australasia Pty. Ltd., Chatswood, NSW, Australia).

\section{Results}

\section{Acute asthma}

Fifteen patients were recruited for the study. Basic demographic and albuterol utilisation in the previous 24 $h$ are summarised in Table 1 . The initial baseline respiratory test (PEF) was not performed in three subjects, partly because of the severity of their symptoms, but was estimated by clinicians to be less than $25 \%$ of the predicted value.

Plasma albuterol enantiomer levels were measured in all subjects (Table 2 and Figure 1). There were no

Table 1 Subject's demographic and rac-albuterol utilisation among patients presenting to DEM with acute asthma

\begin{tabular}{lc}
\hline & $\begin{array}{c}\text { Median (range) } \\
\mathbf{N}=\mathbf{1 5}\end{array}$ \\
\hline Age & $38(22-65)$ \\
Gender & $\begin{array}{c}6 \text { male; } 9 \\
\text { female }\end{array}$ \\
Smoking history (medical record) & \\
$\quad$ Current smoker & 5 \\
$\quad$ Ex-smoker & 2 \\
Respiratory test, \% predicted PEF ( $n=12)$ & \\
$\quad$ Baseline & $51(21-69)$ \\
$\quad 60-$ min post-initial test & $60(31-78)$ \\
Total rac-albuterol utilisation in preceding 24 h & $3.0(0.8-11.0)$ \\
(DDDs) & \\
Total dose delivered via MDI & $1.5(0.0-5.3)$ \\
Total dose delivered via nebuliser & $2.0(0.0-5.5)$ \\
Total dose delivered by health-care officer & $1.5(0.0-0.25)$ \\
\hline
\end{tabular}


Table 2 Correlation between rac-albuterol dose utilisation [median (range)] and serum albuterol enantiomer levels [median (range)] among acute asthma subjects

\begin{tabular}{lccc}
\hline & & \multicolumn{2}{c}{ Albuterol utilisation } \\
& Serum level & $\begin{array}{c}\text { Total dose utilisation } \\
\text { a }\end{array}$ & $\begin{array}{c}\text { Recorded dose utilisation }{ }^{\mathbf{b}} \\
\mathbf{2 0 . 0}(\mathbf{0 . 6}-\mathbf{5 5 . 0} \mathbf{~ ( 0 . 0 - 5 0 . 0 ) ~} \mathbf{~ m g}\end{array}$ \\
\hline (R)-albuterol & $8.2(0.6-24.8) \mathrm{ng} / \mathrm{mL}$ & $r^{2}=0.22$ & $r^{2}=0.54^{*}$ \\
(S)-albuterol & $20.6(0.5-57.3) \mathrm{ng} / \mathrm{mL}$ & $r^{2}=0.50$ & $r^{2}=0.33$ \\
Total albuterol & $28.9(1.1-73.3) \mathrm{ng} / \mathrm{mL}$ & $r^{2}=0.43$ & $r^{2}=0.42$ \\
\hline
\end{tabular}

Two-tailed Pearson correlation test

${ }^{\mathrm{a}}$ Dose administered in the preceding $24 \mathrm{~h}$, including dose administered prior to the hospital presentation

${ }^{b}$ Dose administered by health-care officer, as recorded in hospital medical history ${ }^{*} p<0.05$

relationships between plasma albuterol enantiomer levels and severity or response to treatment, measured both by the four-point severity score (Table 3 ) and percent improvement in predicted PEF at $60 \mathrm{~min}$. Patients with higher levels of $24 \mathrm{~h} \mathrm{rac}$-albuterol utilisation (DDDs), consistent with greater morbidity, had a lower percent predicted PEF at baseline $\left(r^{2}=0.33, p=0.03\right)$, but not a poorer response to therapy measured using the severity score $[\mathrm{F}(2,12)=1.83, p=0.20]$.

Neither smoking history nor the use of inhaled corticosteroids was associated with albuterol used (DDD), the percent improvement in predicted PEF at $60 \mathrm{~min}$ or the severity score. Subjects who had been using long-acting $\beta_{2^{-}}$ agonists were found to be more likely to have used less racalbuterol in the previous $24 \mathrm{~h}$ before presentation $(p=0.02)$.

\section{Acute COPD}

Thirty-seven patients were recruited for the COPD phase of the study, where 25 of the subjects had a recorded medical history of a cardiovascular comorbidity (Table 4).

Serum albuterol enantiomer levels were measured in all subjects (Table 5 and Figure 2), with a weak correlation observed between albuterol dose $(\mathrm{mg})$ and total

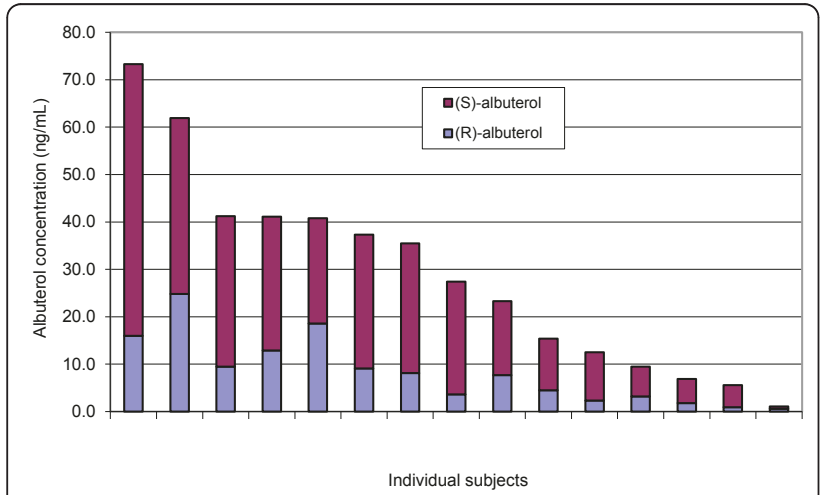

Figure 1 Plasma albuterol enantiomer levels observed among subjects presenting with acute asthma exacerbation $(n=15)$. albuterol as well as (R)- and (S)-albuterol enantiomer levels.

ECG measurements were available in the medical records for 28 subjects, but 2 subjects' ECG measurements were excluded from analysis because of a concurrent digoxin toxicity and a probable atrial flutter, respectively. Six subjects (3 male and 3 female) were identified with prolonged QTc intervals ( $>440 \mathrm{~ms}$ and $>450 \mathrm{~ms}$ for males and females respectively); however, these were not associated with serum levels of total albuterol $(p=0.05)$. Results of serum albuterol levels, heart rate and QTc interval are summarised in Table 6.

The serum potassium levels were recorded in 34 subjects, and the BSLs were recorded in 31 subjects. However, 24 of the serum potassium results were considered inconclusive and excluded from the analysis because of the subjects' medication histories (potassium supplements, diuretics and i.v. fluid infusion) and/or faulty specimens (suspected haemolysed sample). Similarly, 17 of the BSL results were also excluded from analysis because of the subjects' medical (diabetes) and medication histories (oral/i.v. corticosteroids and i.v. fluid infusion). The serum potassium level and BSL from most of the remaining subjects were recorded within the 'normal' physiological range (3.7-5.2 $\mathrm{mmol} / \mathrm{L}$ and 4.0-7.5 $\mathrm{mmol} / \mathrm{L}$ respectively), except for one subject with a slightly lower serum potassium level and four subjects with elevated BSL, but all were not associated with higher than average albuterol enantiomer levels (Table 6).

Table 3 Severity score* and albuterol plasma levels

\begin{tabular}{|c|c|c|c|c|}
\hline \multicolumn{5}{|c|}{ Median (range) plasma levels $\mathrm{ng} / \mathrm{mL}$} \\
\hline $\begin{array}{l}\text { Severity } \\
\text { score }\end{array}$ & $\begin{array}{c}\text { Total } \\
\text { albuterol }\end{array}$ & $\begin{array}{c}\text { (R)- } \\
\text { albuterol }\end{array}$ & $\begin{array}{c}\text { (S)- } \\
\text { albuterol }\end{array}$ & $\begin{array}{c}S: R \\
\text { ratio }\end{array}$ \\
\hline $2(n=8)$ & $21.5(1.1-61.9)$ & $4.1(0.6-24.8)$ & $\begin{array}{c}17.4 \\
(0.5-37.1)\end{array}$ & $\begin{array}{c}3.0 \\
(0.8-6.6)\end{array}$ \\
\hline $3(n=4)$ & $32.3(9.5-73.3)$ & $\begin{array}{c}10.3 \\
(3.2-16.0)\end{array}$ & $\begin{array}{c}22.0 \\
(6.3-57.3)\end{array}$ & $\begin{array}{c}2.1 \\
(2.0-3.6)\end{array}$ \\
\hline $4(n=3)$ & $35.5(5.6-40.8)$ & $8.1(0.9-18.6)$ & $\begin{array}{c}22.1 \\
(4.7-27.4)\end{array}$ & $\begin{array}{c}3.4 \\
(1.2-5.2)\end{array}$ \\
\hline
\end{tabular}

*Modified from the Acute Asthma Index; AAI [36] 
Table 4 Subject demographics and (R/S)-albuterol utilisation among acute COPD patients presenting to DEM

\begin{tabular}{lc}
\hline & $\begin{array}{c}\text { Median (range) } \\
(\boldsymbol{n}=\mathbf{3 7})\end{array}$ \\
\hline Age & $70(51-85)$ \\
Gender & 13 male; 24 female \\
Smoking history (medical record) & 14 \\
Ex-smoker & 18 \\
Comorbidity with asthma & 5 \\
Cardiovascular comorbidity & 11 \\
Ischaemic heart disease $_{\text {Heart failure }}$ & 4 \\
AF & 2 \\
Past AMl & 4 \\
Total (DDD) rac-albuterol delivered $^{\text {a }}$ & 0.5 (0.0-4.0) \\
\hline
\end{tabular}

${ }^{a}$ Dose delivered by health-care professionals include paramedic, doctor and nursing staff

\section{Discussion}

This study reflects the variations in the presentation of acute exacerbations of asthma and COPD in a typical emergency department setting, both in disease severity and the treatment required. However, the relationship between dose and plasma/serum level of albuterol appears to be minor $\left(r^{2} \leq 0.4\right)$.

In comparison with some previously reported data $[8,9,35]$, the levels of albuterol enantiomers observed in this study appeared to be considerably higher, particularly among acutely asthmatic patients. In addition, the accumulation of (S)-albuterol and variation in the R:S ratio highlight the need for enantioselective assays when measuring albuterol in a clinical setting.

Recent reviews have raised concerns about the safety of using large doses of $\beta_{2}$-agonists, especially in patients with underlying cardiovascular comorbidity [27-29]. It has been demonstrated that significant extrapulmonary effects can be observed in subjects given nebulised rac-

Table 5 Correlation between rac-albuterol dose utilisation [median (range)] and serum albuterol enantiomer levels [median (range)], among acute COPD subjects

\begin{tabular}{lcc}
\hline & Serum level & $\begin{array}{c}\text { Albuterol utilisation } \\
\mathbf{5 . 0}\end{array}$ \\
\hline (R)-albuterol & $2.1(0.0-16.7) \mathrm{ng} / \mathrm{mL}$ & $r^{2}=0.34$ \\
(S)-albuterol & $3.5(0.0-36.1) \mathrm{ng} / \mathrm{mL}$ & $r^{2}=0.36 *$ \\
Total albuterol & $5.8(0.0-53.0) \mathrm{ng} / \mathrm{mL}$ & $r^{2}=0.36 *$ \\
\hline
\end{tabular}

${ }^{a}$ Dose administered by health-care officer, as recorded in hospital medical history

${ }^{*} p<0.01$

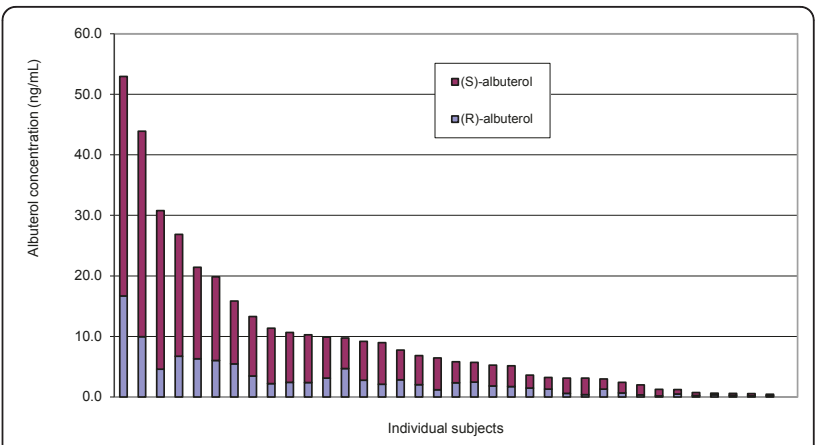

Figure 2 Serum albuterol enantiomer levels observed among subjects presenting with acute exacerbation of COPD $(n=30)$

albuterol at a dose of as little as $6.5 \mathrm{mg}[9,24,26]$. In this study, we observed relatively high albuterol levels in the circulation (some more than 10 times the level observed in the study by Lotvall et al. [24]), but we observed no corresponding variation in extrapulmonary parameters among these patients. The QTc intervals showed minimal change from the commonly regarded normal physiological range, and had no significant relationship with (R)-, (S)- or total albuterol levels (Figure 3 ). However, evaluation of other metabolic effects of albuterol were more difficult because of complex medication regimens, disease comorbidites, as well as potential psychological (e.g. emotional stress) and physiological (e.g. compensation to respiratory stress) effects. A larger study with greater power may be more helpful to elucidate the other metabolic effects and control for complex medication regimens. The results of this investigation are in line with a previous study that found minimal change in QTc intervals after repeated dosing of a high dose of $\beta_{2}$-agonist [36]. The findings suggest that the potential extrapulmonary effects of albuterol do not appear to be problematic among patients who use inhaled rac-albuterol for the acute relief of shortness of breath, even among patients with underlying cardiovascular comorbidity. However, the long-term effects of accumulation of high concentrations of albuterol enantiomer remain unknown and are the subject of ongoing work.

The wide variation in the relationship between dose and levels has also indicated the difficulties in spot sampling methodology without a population pharmacokinetic model [37], as well as the potential impact from the subject's inhalation technique, particularly when an MDI device is used [38-40].

\section{Conclusions}

High plasma concentrations of albuterol were observed in both asthma and COPD patients presenting to the 
Table 6 Mean (range) ECG measurements (HR and QTc interval), serum potassium level and BSL for each tertile of albuterol enantiomer serum level

\begin{tabular}{|c|c|c|c|}
\hline Albuterol concentration (range) & $\begin{array}{l}\text { (R)-albuterol } \\
\text { Lower }(0.0-1.2 \mathrm{ng} / \mathrm{mL}) \\
\text { Middle }(1.3-2.5 \mathrm{ng} / \mathrm{mL}) \\
\text { Upper }(2.8-16.7 \mathrm{ng} / \mathrm{mL})\end{array}$ & $\begin{array}{l}\text { (S)-albuterol } \\
\text { Lower }(0.0-2.1 \mathrm{ng} / \mathrm{mL}) \\
\text { Middle }(2.5-6.8 \mathrm{ng} / \mathrm{mL}) \\
\text { Upper }(6.9-36.3 \mathrm{ng} / \mathrm{mL})\end{array}$ & $\begin{array}{l}\text { Total albuterol } \\
\text { Lower }(0.0-3.1 \mathrm{ng} / \mathrm{mL}) \\
\text { Middle }(3.2-9.7 \mathrm{ng} / \mathrm{mL}) \\
\text { Upper }(9.9-53.0 \mathrm{ng} / \mathrm{mL})\end{array}$ \\
\hline $\begin{array}{l}\mathrm{HR}(/ \min ) \\
(n=26)\end{array}$ & $\begin{array}{c}89(70-120) \\
103(59-127) \\
109(96-137)\end{array}$ & $\begin{array}{c}88(70-120) \\
102(59-120) \\
109(96-137)\end{array}$ & $\begin{array}{c}89(70-120) \\
102(59-120) \\
109(100-137)\end{array}$ \\
\hline $\begin{array}{l}\text { QTc interval (ms) } \\
(n=26)\end{array}$ & $\begin{array}{l}425(386-486) \\
438(374-481) \\
384(363-404)\end{array}$ & $\begin{array}{l}425(374-481) \\
413(377-486) \\
385(363-427)\end{array}$ & $\begin{array}{l}425(386-481) \\
427(374-486) \\
385(363-406)\end{array}$ \\
\hline $\begin{array}{l}\text { Serum potassium level }(\mathrm{mmol} / \mathrm{L}) \\
(n=10)\end{array}$ & $\begin{array}{c}4.7(4.4-5.3) \\
3.5(-) \\
4.4(4.1-5.1)\end{array}$ & $\begin{array}{l}4.0(3.9-5.3) \\
4.1(3.5-5.1) \\
4.4(3.9-5.0)\end{array}$ & $\begin{array}{l}4.0(3.9-5.3) \\
3.8(3.5-4.1) \\
4.6(3.9-5.0)\end{array}$ \\
\hline $\begin{array}{l}\text { BSL }(\mathrm{mmol} / \mathrm{L}) \\
(n=15)\end{array}$ & $\begin{array}{l}6.7(5.2-13.3) \\
6.0(5.4-7.8) \\
7.3(5.7-10.4)\end{array}$ & $\begin{array}{l}6.7(5.2-13.3) \\
6.7(5.8-7.8) \\
6.2(5.4-10.4)\end{array}$ & $\begin{array}{c}6.7(5.2-13.3) \\
6.1(5.4-7.8) \\
6.8(5.7-10.4)\end{array}$ \\
\hline
\end{tabular}

emergency department. Extrapulmonary cardiac adverse effects (prolonged QTC interval) were not associated with the plasma level of rac-albuterol when administered by an inhaler in the emergency department setting. Long-term effect(s) of continuous high circulating albuterol enantiomer concentrations remain unknown, and further investigations are required.

\section{Consent}

Subjects provided written informed consent and the study was approved by the Tasmanian Human Research and Ethics Committee in accordance with the Helsinki Declaration.

\section{Acknowledgements}

The authors wish to acknowledge the staff of the RHH DEM for their assistance with patient recruitment, RHH Department of Clinical Chemistry for assistance with sample collection, and Dr Noel Davies (Central Science Laboratory, University of Tasmania) for assistance with the LC-MS analysis of (R/S)-albuterol. The authors also wish to thank the Asthma Foundation Australia (Tasmania branch) and School of Pharmacy, University of Tasmania, for scholarship and project funding respectively. (a)

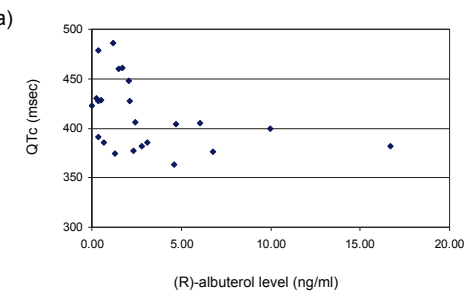

(d)

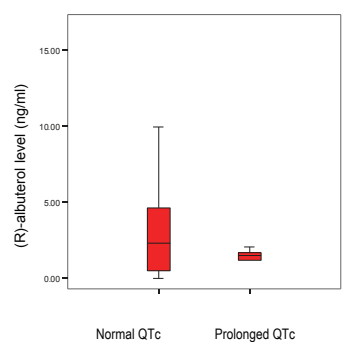

(b)

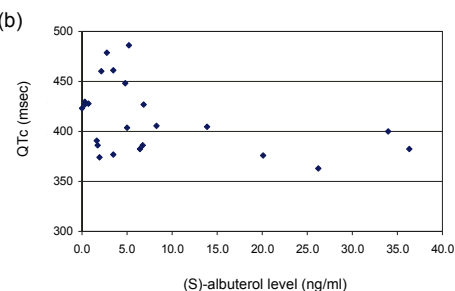

(e)

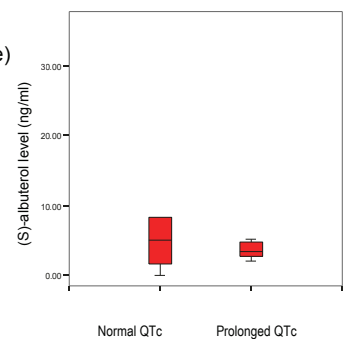

(c)

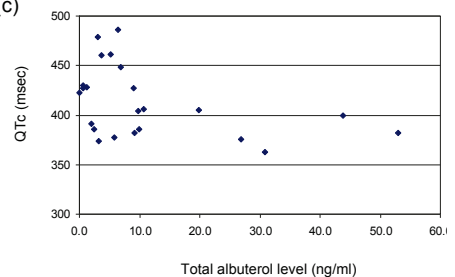

(f)

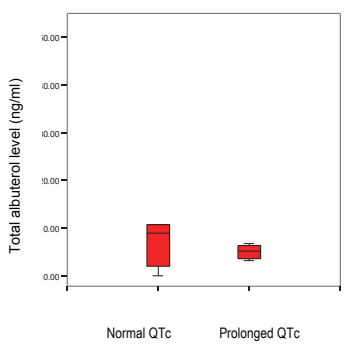

Figure 3 Relationship between QTc interval and albuterol levels. Recorded QTc interval and (R)-, (S)- and total albuterol levels and are shown in (a), (b) and (c) respectively. (R)-, (S)- and total albuterol levels in subjects with normal or prolonged QTc interval are shown in (d), (e) and (f). 


\section{Author details}

${ }^{1}$ School of Pharmacy, University of Tasmania, Hobart, Tasmania, Australia ${ }^{2}$ Menzies Research Institute, University of Tasmania and Department of Respiratory Medicine, Royal Hobart Hospital, Hobart, Tasmania, Australia

\section{Authors' contributions}

GAJ, RWB, and EHW conceived the study, and participated in its design and coordination. KCY coordinated the study patient recruitment, data collection and undertook the laboratory analysis. KYC and GAJ performed the statistical analysis. All authors helped draft the manuscript. All authors read and approved the final manuscript.

\section{Competing interests}

The authors declare that they have no competing interests.

Received: 29 November 2010 Accepted: 15 June 2011

Published: 15 June 2011

\section{References}

1. Renzoni E, Robinson S, Poole P, Ram FS: Short-acting beta 2 agonists for stable chronic obstructive pulmonary disease. Cochrane Database Syst Rev 2002, 4: CD001495

2. Emerman $\mathrm{CL}$, Cydulka RK: Effect of different albuterol dosing regimens in the treatment of acute exacerbation of chronic obstructive pulmonary disease. Ann Emerg Med 1997, 29(4):474-8.

3. Nair S, Thomas E, Pearson SB, Henry MT: A randomized controlled trial to assess the optimal dose and effect of nebulized albuterol in acute exacerbations of COPD. Chest 2005, 128(1):48-54

4. Israel E, Chinchilli VM, Ford JG, Boushey HA, Cherniack R, Craig TJ, Deykin A, Fagan JK, Fahy JV, Fish J, Kraft M, Kunselman SJ, Lazarus SC, Lemanske RF, Liggett SB, Martin RJ, Mitra N, Peters SP, Silverman E, Sorkness CA, Szefler SJ, Wechsler ME, Weiss ST, Drazen JM: Use of regularly scheduled albuterol treatment in asthma: genotype-stratified, randomised, placebocontrolled cross-over trial. Lancet 2004, 364(9444):1505-12.

5. Hancox RJ, Aldridge RE, Cowan JO, Flannery EM, Herbison GP, McLachlan CR, Town Gl, Taylor DR: Tolerance to beta-agonists during acute bronchoconstriction. Eur Respir J 1999, 14(2):283-7.

6. Walters $\mathrm{EH}$, Walters $\mathrm{J}$ : Inhaled short acting beta2-agonist use in asthma: regular vs as needed treatment. Cochrane Database Syst Rev 2000, , 4: CD001285.

7. Bakale RP, Wald SA, Butler HT, Gao Y, Hong Y, Nie X, Zepp CM: Albuterol. A pharmaceutical chemistry review of R-, S-, and RS-albuterol. Clin Rev Allergy Immunol 1996, 14(1):7-35.

8. Schmekel B, Rydberg I, Norlander B, Sjosward KN, Ahlner J, Andersson RG: Stereoselective pharmacokinetics of S-salbutamol after administration of the racemate in healthy volunteers. Eur Respir J 1999, 13(6):1230-5.

9. Lipworth BJ, Clark DJ, Koch P, Arbeeny C: Pharmacokinetics and extrapulmonary beta 2 adrenoceptor activity of nebulised racemic salbutamol and its R and S isomers in healthy volunteers. Thorax 1997, 52(10):849-52.

10. Boulton DW, Fawcett JP: The pharmacokinetics of levoalbuterol: what are the clinical implications? Clin Pharmacokinet 2001, 40(1):23-40.

11. Agrawal DK, Ariyarathna K, Kelbe PW: (S)-Albuterol activates proconstrictory and pro-inflammatory pathways in human bronchial smooth muscle cells. J Allergy Clin Immunol 2004, 113(3):503-10.

12. Ameredes BT, Calhoun WJ: Modulation of GM-CSF release by enantiomers of beta-agonists in human airway smooth muscle. J Allergy Clin Immunol 2005, 116(1):65-72.

13. Hoshiko K, Morley J: Exacerbation of airway hyperreactivity by (+/-) salbutamol in sensitized guinea pig. Jpn J Pharmacol 1993, 63(2):159-63.

14. Johansson F, Rydberg I, Aberg G, Andersson RG: Effects of albuterol enantiomers on in vitro bronchial reactivity. Clin Rev Allergy Immunol 1996, 14(1):57-64.

15. Boulton DW, Fawcett JP: Pharmacokinetics and pharmacodynamics of single oral doses of albuterol and its enantiomers in humans. Clin Pharmacol Ther 1997, 62(2):138-44.
16. Nelson HS, Bensch G, Pleskow WW, DiSantostefano R, DeGraw S, Reasner DS, Rollins TE, Rubin PD: Improved bronchodilation with levalbuterol compared with racemic albuterol in patients with asthma. $J$ Allergy Clin Immunol 1998, 102(6 Pt 1):943-52.

17. Pleskow WW, Nelson HS, Schaefer K, Claus R, Roach JM: Pairwise comparison of levalbuterol versus racemic albuterol in the treatment of moderate-to-severe asthma. Allergy Asthma Proc 2004, 25(6):429-36.

18. Truitt T, Witko J, Halpern M: Levalbuterol compared to racemic albuterol: efficacy and outcomes in patients hospitalized with COPD or asthma. Chest 2003, 123(1):128-35.

19. Barnes PJ: Treatment with (R)-albuterol has no advantage over racemic albuterol. Am J Respir Crit Care Med 2006, 174(9):969-72, discussion 972-4.

20. O'Riordan TG, Mao W, Palmer LB, Chen Jj: Assessing the effects of racemic and single-enantiomer albuterol on airway secretions in long-term intubated patients. Chest 2006, 129(1):124-32.

21. Westerhof FJ, Zuidhof $A B$, Kok L, Meurs H, Zaagsma J: Effects of salbutamo and enantiomers on allergen-induced asthmatic reactions and airway hyperreactivity. Eur Respir J 2005, 25(5):864-72.

22. Ahrens $\mathrm{R}$, Weinberger $\mathrm{M}$ : Levalbuterol and racemic albuterol: are there therapeutic differences? J Allergy Clin Immunol 2001, 108(5):681-4.

23. Gumbhir-Shah K, Kellerman DJ, DeGraw S, Koch P, Jusko WJ: Pharmacokinetics and pharmacodynamics of cumulative single doses of inhaled salbutamol enantiomers in asthmatic subjects. Pulm Pharmacol Ther 1999, 12(6):353-62.

24. Lotvall J, Palmqvist M, Arvidsson P, Maloney A, Ventresca GP, Ward J: The therapeutic ratio of R-albuterol is comparable with that of RS-albuterol in asthmatic patients. J Allergy Clin Immunol 2001, 108(5):726-31.

25. Abramson MJ, Bailey MJ, Couper FJ, Driver JS, Drummer OH, Forbes AB, McNeil JJ, Haydn Walters E: Are asthma medications and management related to deaths from asthma? Am J Respir Crit Care Med 2001, 163(1):12-8

26. Handley DA, Tinkelman D, Noonan M, Rollins TE, Snider ME, Caron J: Doseresponse evaluation of levalbuterol versus racemic albuterol in patients with asthma. J Asthma 2000, 37(4):319-27.

27. Salpeter SR, Ormiston TM, Salpeter EE: Cardiovascular effects of betaagonists in patients with asthma and COPD: a meta-analysis. Chest 2004, 125(6):2309-21.

28. Kallergis EM, Manios EG, Kanoupakis EM, Schiza SE, Mavrakis HE, Klapsinos NK, Vardas PE: Acute electrophysiologic effects of inhaled salbutamol in humans. Chest 2005, 127(6):2057-63.

29. Cazzola M, Matera MG, Donner CF: Inhaled beta2-adrenoceptor agonists: cardiovascular safety in patients with obstructive lung disease. Drugs 2005, 65(12):1595-610.

30. Jacobson GA, Chong FV, Wood-Baker R: (R, S)-salbutamol plasma concentrations in severe asthma. J Clin Pharm Ther 2003, 28(3):235-8.

31. Australia N.A.C: Asthma management handbook 2006. South Melbourne, Australia: National Asthma Council Australia Ltd; , Sixth 2006.

32. Bell HM, McElnay JC, Hughes CM: Changing profile in the use of antiasthma drugs. Pharmacoepidemiol Drug Saf 1999, 8(6):385-94.

33. Rodrigo G, Rodrigo C: Early prediction of poor response in acute asthma patients in the emergency department. Chest 1998, 114(4):1016-21.

34. Jacobson GA, Chong FV, Davies NW: LC-MS method for the determination of albuterol enantiomers in human plasma using manual solid-phase extraction and a non-deuterated internal standard. J Pharm Biomed Anal 2003, 31(6):1237-43.

35. Ward JK, Dow J, Dallow N, Eynott P, Milleri S, Ventresca GP: Enantiomeric disposition of inhaled, intravenous and oral racemic-salbutamol in manno evidence of enantioselective lung metabolism. Br J Clin Pharmacol 2000, 49(1):15-22.

36. Rosenkranz B, Rouzier R, Kruse M, Dobson C, Ayre G, Horowitz A, Fitoussi S: Safety and tolerability of high-dose formoterol (via Aerolizer) and salbutamol in patients with chronic obstructive pulmonary disease. Respir Med 2006, 100(4):666-72.

37. Hussein R, Charles BG, Morris RG, Rasiah RL: Population pharmacokinetics of perhexiline from very sparse, routine monitoring data. Ther Drug Monit 2001, 23(6):636-43.

38. Devadason SG: Recent advances in aerosol therapy for children with asthma. J Aerosol Med 2006, 19(1):61-6. 
39. Melani AS: Inhalatory therapy training: a priority challenge for the physician. Acta Biomed 2007, 78(3):233-45

40. Virchow JC: Guidelines versus clinical practice-which therapy and which device? Respir Med 2004, 98(Suppl B):S28-34.

doi:10.1186/1865-1380-4-30

Cite this article as: Yee et al:: Albuterol enantiomer levels, lung function and QTc interval in patients with acute severe asthma and COPD in the emergency department. International Journal of Emergency Medicine 2011 4:30

\section{Submit your manuscript to a SpringerOpen ${ }^{\mathcal{O}}$ journal and benefit from:}

- Convenient online submission

- Rigorous peer review

- Immediate publication on acceptance

- Open access: articles freely available online

- High visibility within the field

- Retaining the copyright to your article

Submit your next manuscript at $\gg$ springeropen.com 